\title{
The Constituents and Their Bioactivities of Houttuynia cordata
}

\author{
Shu-Chen Chou, ${ }^{a}$ Chung-Ren Su, ${ }^{a}$ Yuh-Chi Ku, ${ }^{b}$ and Tian-Shung $\mathrm{Wu}^{*, a, c}$ \\ ${ }^{a}$ Department of Chemistry, National Cheng Kung University; Tainan 701, Taiwan: ${ }^{b}$ Department of Life Science, Fu-Jen \\ University; Taipei Hsien 242, Taiwan: and ${ }^{c}$ Department of Pharmacy, China Medical University; Taichung 401, Taiwan. \\ Received May 5, 2009; accepted July 8, 2009; published online August 17, 2009
}

\begin{abstract}
Chemical investigation on the whole plant of Houttuynia cordata has resulted in the isolation of two new compounds, named as houttuynoside A (1) and houttuynamide A (2), together with thirty-eight known compounds. The structures of 1 and 2 were elucidated on the basis of spectroscopic analysis. In the inhibitory effects on herpes simplex virus type 1 (HSV-1) assay, norcepharadione B (10) showed good inhibitory activity against the replication of HSV-1. In addition, the antioxidant and antityrosinase activities of some isolated compounds were also evaluated. Among these compounds, quercitrin (25) and quercetin-3- $O$ - $\beta$-D-galactopyranoside (26) showed excellent 2,2-diphenyl-1-picrylhydrazyl radical-scavenging property with $\mathrm{IC}_{50}$ values of 31 and $63 \mu \mathrm{M}$, respectively. Cepharadione B (9) exhibited strong tyrosinase inhibitory activity with an $\mathrm{IC}_{50}$ value of $170 \mu_{\mathrm{M}}$.
\end{abstract}

Key words Euphorbiaceae; herpes simplex virus type 1; antioxidant; antityrosinase

Houttuynia cordata ThunB. (Saururaceae) is a native perennial herbaceous plant in the eastern and southern regions of Asia. Recently, H. cordata has been used for the treatment of herpes simplex virus type 1 (HSV-1), influenza virus, human immunodeficiency virus type 1 (HIV-1), ${ }^{1)}$ and chronic sinusitis and nasal polyps. ${ }^{2)}$ Besides, the whole plant has also been reported to have the antileukemic activity, ${ }^{3)}$ anticancer activity, ${ }^{4)}$ adjuvanticity, ${ }^{5)}$ antioxidant action, ${ }^{6)}$ and inhibitory effects on anaphylactic reaction and mast cell activation. ${ }^{2}$ In our continuing research for bioactive compounds from medicinal plants, this paper deals with isolation, structure elucidation of the new compounds, and evaluation of the anti-herpes simplex virus activity 1 (HSV-1), the antioxidant, and antityrosinase activities of the isolated compounds.

\section{Results and Discussion}

The $\mathrm{MeOH}$ extract of $H$. cordata was partitioned with $\mathrm{CHCl}_{3}$ and $\mathrm{H}_{2} \mathrm{O}$. The condensed chloroform extract was portioned with $n$-hexane and $80 \% \mathrm{CH}_{3} \mathrm{OH}_{\mathrm{aq}}$. The $\mathrm{H}_{2} \mathrm{O}$-soluble portion was further portioned with $n$-BuOH to give a dark brown syrup. Through the further isolation of the subfractions, it led to two new compounds and thirty-eight known compounds.

Houttuynoside A (1) was isolated as optically active colorless syrup. The HR-FAB-MS of $\mathbf{1}$ exhibited a pesudomolecular ion peak at $m / z 451.1244$, consistent with the molecular formula $\mathrm{C}_{21} \mathrm{H}_{22} \mathrm{O}_{11}$. The IR spectrum showed absorption bands at 3392 and $1688 \mathrm{~cm}^{-1}$ were assignable to hydroxyl and carbonyl moieties. ${ }^{1} \mathrm{H}-\mathrm{NMR}$ spectrum showed the presence of a set of ABX protons at $\delta_{\mathrm{H}} 7.50(1 \mathrm{H}, \mathrm{d}, J=2.9 \mathrm{~Hz}$, $\mathrm{H}-2), 7.33(1 \mathrm{H}, \mathrm{dd}, J=9.0,2.9 \mathrm{~Hz}, \mathrm{H}-6)$, and $6.79(1 \mathrm{H}, \mathrm{d}$, $J=9.0 \mathrm{~Hz}, \mathrm{H}-5)$, a set of $\mathrm{A}_{2} \mathrm{~B}_{2}$-type aromatic protons at $\delta$ $7.88\left(2 \mathrm{H}, \mathrm{d}, J=8.6 \mathrm{~Hz}, \mathrm{H}-2^{\prime \prime},-6^{\prime \prime}\right)$ and $6.90(2 \mathrm{H}, \mathrm{d}, J=8.6 \mathrm{~Hz}$, $\left.\mathrm{H}-3^{\prime \prime},-5^{\prime \prime}\right)$, and one glucopyranose unit. A three protons singlet signal at $\delta 3.84$ was assigned for a methoxy group. According to the ${ }^{1} \mathrm{H}$ - and ${ }^{13} \mathrm{C}$-NMR spectral data, it indicated that the presence of a 4-hydroxybenzoate, 3,4-dihydroxybenzoate, and glucopyranosyl moiety. Acid hydrolysis of $\mathbf{1}$ and chromatographic purification afforded D-glucose which was compared with authentic sample of D-glucose. In addition, the anomeric signal at $\delta 4.33(1 \mathrm{H}, \mathrm{dd}, J=11.7,7.2 \mathrm{~Hz}) \mathrm{sug}$ gested the presence of a sugar residue with a $\beta$-D-glucosyl moiety. The 4-hydroxybenzoate moiety and 3,4-dihydroxybenzoate moiety were linked through glucosyl moiety at C- $6{ }^{\prime}$ and $\mathrm{C}-1^{\prime}$, which were based on the heteronuclear multiple bond coherence (HMBC) correlations with H-6 $\left(\delta_{\mathrm{H}}=4.70\right.$, 4.33, each $1 \mathrm{H})$ to $\mathrm{C}-7^{\prime \prime}\left(\delta_{\mathrm{C}} 165.8\right)$ and $\mathrm{H}-1^{\prime}(\delta 4.90)$ to $\delta$ 150.3 (C-3), respectively. From the above spectroscopic data, the structure of houttuynoside A was identified as $\mathbf{1}$.

Houttuynamide A (2) was isolated as colorless syrup. The molecular formula of 2 was determined as $\mathrm{C}_{15} \mathrm{H}_{15} \mathrm{NO}_{2}$ from molecular ion peak at $m / z 273.1004$ in the HR-EI-MS. The IR spectrum displayed absorptions at 3353 and $1700 \mathrm{~cm}^{-1}$, due to hydroxyl and carbonyl groups. A 1,3,4-trisubstituted phenyl group was observed in the ${ }^{1} \mathrm{H}$ - and ${ }^{13} \mathrm{C}$-NMR spectra [ABX system at $\delta_{\mathrm{H}} 7.24(1 \mathrm{H}, \mathrm{d}, J=2.0 \mathrm{~Hz}, \mathrm{H}-2), 7.15(1 \mathrm{H}$, $\mathrm{dd}, J=8.4,2.0 \mathrm{~Hz}, \mathrm{H}-6)$, and $6.78(1 \mathrm{H}, \mathrm{d}, J=8.4 \mathrm{~Hz}, \mathrm{H}-5) ; \delta_{\mathrm{C}}$ 115.7 (C-2), 115.8 (C-5), 120.5 (C-6), 127.2 (C-1), 146.3 (C$3)$ and $150.0(\mathrm{C}-4)]$ and the attachment of a $-\mathrm{CONCH}_{2} \mathrm{CH}_{2}-$ group $\left[\delta_{\mathrm{H}} 3.49\left(2 \mathrm{H}, \mathrm{t}, J=7.5 \mathrm{~Hz}, \mathrm{H}-8^{\prime}\right)\right.$ and $2.78(2 \mathrm{H}, \mathrm{t}$, $\left.J=7.5 \mathrm{~Hz}, \mathrm{H}-7^{\prime} ; \delta_{\mathrm{C}} 170.2(\mathrm{C}-7)\right]$ to the aromatic nucleus. This was confirmed by ${ }^{3} J$-HMBC correlations from $\mathrm{H}-2$ and $\mathrm{H}-6$ to $\mathrm{C}-7$ and from $\mathrm{H}-8^{\prime}$ to $\mathrm{C}-7$ ( $\delta$ 170.2). The ${ }^{1} \mathrm{H}-$ and ${ }^{13} \mathrm{C}-$ NMR spectra of 2 also revealed the presence of a para substituted phenyl group $\left[\mathrm{A}_{2} \mathrm{~B}_{2}\right.$ system at $\delta_{\mathrm{H}} 7.06(2 \mathrm{H}, \mathrm{d}$, $\left.J=8.6 \mathrm{~Hz}, \mathrm{H}-2^{\prime},-6^{\prime}\right)$ and $6.71\left(2 \mathrm{H}, \mathrm{d}, J=8.6 \mathrm{~Hz}, \mathrm{H}-3^{\prime},-5^{\prime}\right)$; $\delta_{\mathrm{C}} 116.5\left(\mathrm{C}-3^{\prime},-5^{\prime}\right), 130.1\left(\mathrm{C}-2^{\prime},-6^{\prime}\right), 131.5\left(\mathrm{C}-1^{\prime}\right)$ and $\left.156.9\left(\mathrm{C}-4^{\prime}\right)\right]$ to which is attached a $-\mathrm{CH}_{2} \mathrm{CH}_{2} \mathrm{~N}-$ group as evidenced by HMBC correlations from $\mathrm{H}-7^{\prime}$ to $\mathrm{C}-2^{\prime}, \mathrm{C}-6^{\prime}$ and $\mathrm{C}-8^{\prime}$. These data indicated these two phenyl ring moieties were connected through $-\mathrm{CH}_{2} \mathrm{CH}_{2} \mathrm{NHCO}-$ linkage.
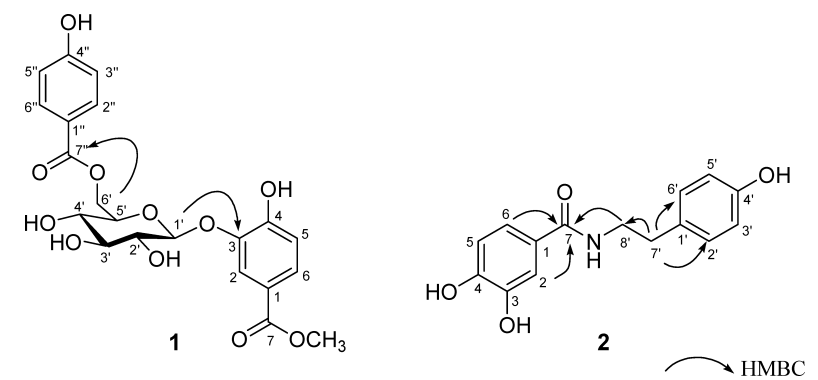

Fig. 1. Structures and Significant HMBC Correlations of Houttuynoside A (1) and Houttuynamide A (2) 
From the above spectroscopic data, the structure of $\mathbf{2}$ was determined and named as houttuynamide A.

In addition, thirty-eight known compounds were identified by comparison of their physical and spectroscopic data with those of corresponding authentic samples or literature values. These compounds are aristolactams 3-6 [aristolactam A II (3) ${ }^{7)}$ aristolactam B II (4), ${ }^{7)}$ piperolactam A (5), ${ }^{8)}$ and 3,4dimethoxy- $N$-methyl aristolactam (6) $],{ }^{9)}$ oxoaporphines 7 and 8 [splendidine $(7)^{1)}$ and lysicamine $(\mathbf{8})$ ], ${ }^{10)}$ 4,5-dioxoaporphines 9-11 [cepharadione B (9), ${ }^{8)}$ norcepharadione B (10), ${ }^{8)}$ and noraritolodione (11)], ${ }^{1)}$ amides 12-18 [N-(1hydroxymethyl-2-phenylethyl)benzamide (12), ${ }^{11)} \mathrm{N}$-(4-hydroxyphenylethyl)benzamide $(\mathbf{1 3}),{ }^{12}$ benzamide $(\mathbf{1 4}),{ }^{13)}$ 4hydroxybenzamide (15), ${ }^{14)}$ 4-hydroxy-3-methoxybenzamide (16), ${ }^{15}$ 6,7-dimethyl-1-ribitol-1-yl-1,4-dihydroquinoxaline2,3-dione (17), ${ }^{16}$ and $(1 H)$-quinolinone (18)], ${ }^{17)}$ indole 19 [indole-3-carboxylic acid (19)], ${ }^{18)}$ ionones $\mathbf{2 0 - 2 4}$ [vomifoliol (20), ${ }^{19)}$ dehydrovomifoliol $(\mathbf{2 1}),{ }^{20)}$ reseoside $(\mathbf{2 2}),{ }^{21)} 7$ (3,5,6-trihydroxy-2,6,6-trimethylcyclohexyl)-byt-3-en-2-one $(\mathbf{2 3}){ }^{22)}$ and 6-(9-hydroxy-but-7-ethyl)-1,1,5-trimethylcyclohexane-3,5,6-triol (24)], ${ }^{23)}$ flavonoids 25-27 [quercitrin $(\mathbf{2 5}),{ }^{24)}$ quercetin-3-O- $\beta$-D-galactopyranoside $(\mathbf{2 6}),{ }^{24)}$ and afzelin (27)], ${ }^{24)}$ benzenoids $\mathbf{2 8}-\mathbf{3 7}$ [vanillic acid (28), ${ }^{25)}$ methyl vanillate $(\mathbf{2 9}),{ }^{26)}$ vanillin $(\mathbf{3 0}),{ }^{26)}$ protocatechuic acid $(\mathbf{3 1}),{ }^{27)}$ 4-hydroxybenzoic acid (32), ${ }^{28)}$ methylparaben $(\mathbf{3 3}),{ }^{29)}$ $p$-hydroxybenzaldehyde (34), ${ }^{30)}$ cis and trans-methyl ferulate $(35,36),{ }^{31)}$ and benzyl- $\beta$-D-glucopyranoside $\left.(37)\right],{ }^{32)}$ steroids 38 and $39\left[\beta\right.$-sitosteryl glucoside $(\mathbf{3 8})^{33)}$ and $\beta$-sitosterol $(39)],{ }^{25)}$ as well as a triterpenoid 40 [cycloart-25-ene-3 $\beta, 24-$ diol (40)]. ${ }^{34)}$

Inhibitory effects of isolated compounds $3-\mathbf{5}, \mathbf{9}-\mathbf{1 1}, \mathbf{1 4}$, $\mathbf{2 2}, \mathbf{2 3}, \mathbf{2 5}, \mathbf{2 7}, \mathbf{2 8}, \mathbf{3 1}, \mathbf{3 2}, \mathbf{3 7}$, and $\mathbf{4 0}$ on herpes simplex virus type 1 (HSV-1) replication were investigated as compared with acyclovia. As shown in Table 1, norcepharadione B (10) significantly suppressed HSV-1 replication by $46.38 \pm 1.06 \%$ at the concentration of $100 \mu \mathrm{M}$. Compounds 5, 22, and 27 showed moderate activities with inhibition percentages $20.48 \pm 0.00 \%, 20.45 \pm 1.76 \%$, and $25.44 \pm 1.76 \%$, respectively. Hence, suppression of viral replication of norcepharadione B (10) might have an important implication for $H$. cordata therapeutic activity in virus infection. In addition, the isolated compounds $\mathbf{1 5}, \mathbf{1 6}, \mathbf{2 5}-\mathbf{2 8}, \mathbf{3 0}, \mathbf{3 1}$, and $\mathbf{3 3}$ were also examined for their antioxidant properties using the 2,2diphenyl-1-picrylhydrazyl free radical (DPPH) assay in Table 2. Compounds 25, 26, and $\mathbf{3 1}$ were found to be active at $250 \mu \mathrm{M}$ with inhibition percentages $84 \%, 82 \%$, and $50 \%$, respectively. Quercitrin (25) and quercetin-3- $O-\beta$-D-galactopyranoside (26) exhibited strong scavenging activity with $\mathrm{IC}_{50}$ values of 31 and $63 \mu \mathrm{M}$, respectively, which was compared to the reference compound of vitamin $\mathrm{E}\left(\mathrm{IC}_{50}, 80 \mu \mathrm{M}\right)$. The antityrosinase activities of $3,4,9,10,15,29$, and 34 were also evaluated. Among these compounds, cepharadione B (9) exhibited strong inhibitory activity with an $\mathrm{IC}_{50}$ value of $170 \mu \mathrm{M}$, compared to the reference compound of kojic acid $\left(\mathrm{IC}_{50}\right.$ value $\left.160 \mu \mathrm{M}\right)$.

\section{Experimental}

General Melting points were determined using Yanagimoto MP-S3 micro melting point apparatus and were uncorrected. Optical rotations were measured using a JASCO DIP-370 digital polarimeter. UV spectra were recorded on a Hitachi U-3210 spectrophotometer, and IR spectra were recorded on a Shimadzu FT-IR Prestige-21 spectrophotometer. ${ }^{1} \mathrm{H}$ - and ${ }^{13} \mathrm{C}$ -
Table 1. Effects of Tested Compounds on HSV-1 Replication

\begin{tabular}{cc}
\hline \hline Compounds $(100 \mu \mathrm{M})$ & Inhibitory activity $(\%)$ \\
\hline $\mathbf{3}$ & $8.48 \pm 0.71$ \\
$\mathbf{4}$ & $-3.08 \pm 0.29$ \\
$\mathbf{5}$ & $20.48 \pm 0.00$ \\
$\mathbf{9}$ & $3.24 \pm 2.12$ \\
$\mathbf{1 0}$ & $46.38 \pm 1.06$ \\
$\mathbf{1 1}$ & $17.71 \pm 3.53$ \\
$\mathbf{1 4}$ & $-7.98 \pm 1.76$ \\
$\mathbf{2 2}$ & $20.45 \pm 1.76$ \\
$\mathbf{2 3}$ & $-2.74 \pm 4.23$ \\
$\mathbf{2 5}$ & $2.74 \pm 5.64$ \\
$\mathbf{2 7}$ & $25.44 \pm 1.76$ \\
$\mathbf{2 8}$ & $6.73 \pm 4.49$ \\
$\mathbf{3 1}$ & $5.49 \pm 3.17$ \\
$\mathbf{3 2}$ & $13.47 \pm 3.17$ \\
$\mathbf{3 7}$ & $14.21 \pm 2.82$ \\
$\mathbf{4 0}$ & $3.24 \pm 4.94$ \\
\hline
\end{tabular}

Table 2. The DPPH Radical Scavenging Activities of Tested Compounds

\begin{tabular}{ccc}
\hline \hline Compounds & Activity $(\%)(250 \mu \mathrm{M})$ & $\mathrm{IC}_{50}(\mu \mathrm{M})$ \\
\hline $\mathbf{1 5}$ & N.A. & - \\
$\mathbf{1 6}$ & N.A. & - \\
$\mathbf{2 5}$ & 84 & 31 \\
$\mathbf{2 6}$ & 82 & - \\
$\mathbf{2 7}$ & N.A. & - \\
$\mathbf{2 8}$ & N.A. & - \\
$\mathbf{3 0}$ & N.A. & 250 \\
$\mathbf{3 1}$ & 50 & - \\
$\mathbf{3 3}$ & N.A. & 80 \\
Vitamine E & 74 & \\
\hline
\end{tabular}

N.A.: no activity.

NMR, COSY, HMQC, HMBC, and NOESY spectra were recorded on Bruker AVANCE-300, 500 and AMX-400 spectrometers, using tetramethylsilane (TMS) as internal standard. Standard pulse sequences and parameters were used for the NMR experiments and all chemical shifts are reported in parts per million $(\mathrm{ppm}, \delta$ ). FAB-MS were obtained on a JEOL JMS-700 spectrometer, and EI-MS were obtained on a VG-70-250S spectrometer. Column chromatography was performed on silica gel (70-230 mesh, 230400 mesh). Fractions were monitored by TLC (Merck precoated Si gel 60 F254 plates), using UV light. TLC was conducted on precoated Kieselgel 60 F 254 plates (Merck) and the spots were detected either by examining the plates under a UV lamp or by treating the plates with a $10 \%$ methanolic solution of $p$-anisaldehyde acid followed by heating at $110^{\circ} \mathrm{C}$.

Plant Materials The whole plant of $H$. cordata was collected in Taiwan on July in 2004. The plant material was identified and authenticated by Prof. C. S. Kuoh. A voucher specimen (HC04023) has been deposited in the herbarium of National Cheng Kung University, Tainan, Taiwan.

Extraction and Isolation The air-dried and powdered whole plant of $H$. cordata $(9.4 \mathrm{~kg})$ was extracted with hot $\mathrm{MeOH}(6 \times 201)$ and concentrated under reduced pressure to obtain a dark crude extract $(810 \mathrm{~g})$. Then it was suspended in $\mathrm{H}_{2} \mathrm{O}$ and partitioned with $\mathrm{CHCl}_{3}$ to afford $\mathrm{CHCl}_{3}-(440 \mathrm{~g})$ and $\mathrm{H}_{2} \mathrm{O}$-soluble portions $(360 \mathrm{~g})$, respectively. The condensed chloroform extract was portioned with $n$-hexane and $80 \% \mathrm{CH}_{3} \mathrm{OH}_{\mathrm{aq}}$. The $\mathrm{H}_{2} \mathrm{O}$-soluble portions was further portioned with $n-\mathrm{BuOH}$ to give a dark brown syrup $(100 \mathrm{~g})$.

The $n$-hexane layer was concentrated under reduced pressure to afford a brown syrup (320 g), which was chromatographed on silica gel using gradients of $n$-hexane and ethyl acetate to give six fractions. Fraction 2 was rechromatographed on silica gel using $n$-hexane-ethyl acetate $(29: 1$ to $0: 1)$ as step gradients as eluents to obtain $\mathbf{4 0}(6.7 \mathrm{mg})$. Fraction 3 on column chromatography over silica gel using stepwise gradients of $n$-hexane-ethyl acetate $(18: 1$ to $0: 1)$ afforded the colorless crystal $39(1.1 \mathrm{~g})$. Fraction 4 was rechromatographed on a silica gel column with $n$-hexane- $\mathrm{CHCl}_{3}(2: 1)$ as step gradient mixtures to yield $\mathbf{6}(7.8 \mathrm{mg})$.

The $80 \% \mathrm{CH}_{3} \mathrm{OH}$ layer was concentrated and treated with $2 \% \mathrm{HCl}$ and 
$\mathrm{CHCl}_{3}$. The non-alkaloid layer (HCC) was condensed to obtain a brown syrup (90 g). The acidic water-soluble part was neutralized with $\mathrm{NH}_{4} \mathrm{OH}_{(\mathrm{aq})}$, partitioned with $\mathrm{CHCl}_{3}$, and afforded alkaloidal layer $(18 \mathrm{~g}, \mathrm{HCA})$. The $\mathrm{HCC}$ layer was eluted with step gradient mixtures of $\mathrm{CHCl}_{3}$ and $\mathrm{CH}_{3} \mathrm{OH}$ (29: 1 to $0: 1)$ to afford nine fractions. Fraction 2 was chromatographed over silica gel column chromatography using $\mathrm{CHCl}_{3}-\mathrm{CH}_{3} \mathrm{OH}(99: 1$ to $0: 1)$ as step gradient mixtures as eluents and further purified by repeated column chromatography to give successively 4 (3.3 mg), 9 (2.5 mg), 33 (4.7 mg), and a mixture of 35 and $36(2.1 \mathrm{mg})$. Fraction 3 was chromatographed on silica gel and eluted with $\mathrm{CHCl}_{3}-\mathrm{MeOH}(19: 1)$ to give 10 (3.8 mg). Fraction 4 was further subjected to column chromatography over silica gel using stepwise gradients of diisopropyl ether-acetone $(34: 1$ to $0: 1)$ and then was further isolated on the chromatography to afford $\mathbf{3}(4.1 \mathrm{mg}), \mathbf{5}(4.8 \mathrm{mg}), \mathbf{1 3}$ $(1.4 \mathrm{mg})$, and $16(3.7 \mathrm{mg})$. Fraction 5 was chromatographed on silica gel eluting with step gradient mixtures of diisopropyl ether- $\mathrm{CH}_{3} \mathrm{OH}(5: 1$ to $0: 1$ ) and then purified by preparative thin-layer chromatography to afford 11 $(2.1 \mathrm{mg})$. Fraction 6 was purified on silica gel column using stepwise gradients of $\mathrm{CHCl}_{3}-\mathrm{MeOH}(6: 1$ to $0: 1)$ as eluents to produce $\mathbf{8}(1.2 \mathrm{mg})$ and $\mathbf{3 8}$ $(29.0 \mathrm{mg})$. Fraction 8 was separated on a silica gel column chromatography using $\mathrm{CHCl}_{3}-\mathrm{MeOH}-\mathrm{H}_{2} \mathrm{O}(39: 1: 0.1$ to $0: 1: 0.1)$ as step gradient mixtures as eluents to occur the white precipitate, which was recrystallized by $\mathrm{CH}_{3} \mathrm{OH}$ to yield $25(2.1 \mathrm{~g})$. The HCA layer $(18 \mathrm{~g})$ was chromatographed on a silica gel column eluting with step gradients of $\mathrm{CHCl}_{3}-\mathrm{CH}_{3} \mathrm{OH}(99: 1$ to $0: 1)$ as eluents to give nine fractions. Fraction 2 was separated on a silica gel column chromatography and further purified by preparative TLC with $n$ hexane-ethyl acetate $(9: 1)$ to obtain $\mathbf{2 9}(2.3 \mathrm{mg})$ and $\mathbf{3 0}(1.2 \mathrm{mg})$. Purification of fraction 6 on a silica gel column chromatography eluting with a step gradient of diisopropyl ether-ethyl acetate (14:1 to $1: 1)$ as eluents and further separated by preparative TLC to obtain $34(0.9 \mathrm{mg})$. Fraction 7 was subjected to column chromatography over a silica gel using a stepwise gradient of $n$-hexane-ethyl acetate ( $1: 1$ to $0: 1)$ as eluents and then was further purified on the chromatography to afford $7(1.8 \mathrm{mg})$ and $21(1.2 \mathrm{mg})$. Purification of the fraction 8 by silica gel with $n$-hexane-ethyl acetate $(1: 1$ to $0: 1)$ as step gradient mixtures as eluents and then purified by preparative thinlayer chromatography with $\mathrm{CHCl}_{3}-\mathrm{MeOH}(9: 1)$ to afford $15(2.1 \mathrm{mg}), 31$ $(2.5 \mathrm{mg})$, and $28(2.4 \mathrm{mg})$.

The $n$-BuOH layer $(100 \mathrm{~g})$ was chromatographed over reversed-phase Diaion HP-20 gel using $\mathrm{H}_{2} \mathrm{O}-\mathrm{CH}_{3} \mathrm{OH}$ as step gradients, and afforded seven fractions. Fraction 2 was subjected to silica gel column chromatography using diisopropyl ether- $\mathrm{CH}_{3} \mathrm{OH}(5: 1$ to $0: 1)$ as step gradient mixtures as eluents to afford $19(7.5 \mathrm{mg})$. Fraction 3 was purified on a silica gel column using $\mathrm{CHCl}_{3}-\mathrm{CH}_{3} \mathrm{OH}(7: 1)$ as step gradients as eluent to yield $32(1.7 \mathrm{mg})$ Fraction 4 was separated on a silica gel column chromatography with $\mathrm{CHCl}_{3}-\mathrm{CH}_{3} \mathrm{OH}-\mathrm{H}_{2} \mathrm{O}(5: 1: 0.1)$ and further purified by preparative TLC to obtain successively $17(2.0 \mathrm{mg}), \mathbf{2 2}(4.2 \mathrm{mg}), 23(5.2 \mathrm{mg}), \mathbf{2 4}(3.0 \mathrm{mg})$ and $37(6.0 \mathrm{mg})$. Fraction 5 was separated using a silica gel column with step gradients of diisopropyl ether- $\mathrm{CH}_{3} \mathrm{OH}-\mathrm{H}_{2} \mathrm{O}(5: 1: 0.1$ to $0: 1: 0.1)$ as eluent to give four fractions. Fraction 5-2 occurring the white precipitate was recrystallized by $\mathrm{CH}_{3} \mathrm{OH}$ to yield $26(0.9 \mathrm{~g})$. The subfraction 5-3 was separated on a silica gel column chromatography and further purified by preparative TLC with $\mathrm{CHCl}_{3}-\mathrm{CH}_{3} \mathrm{OH}-\mathrm{H}_{2} \mathrm{O}(7: 1: 0.1)$ to give $14(1.8 \mathrm{mg}), 20$ $(1.9 \mathrm{mg})$, and $2(2.3 \mathrm{mg})$. Fraction 6 was subjected to column chromatography over a silica gel using stepwise gradients of diisopropyl ether- $\mathrm{CH}_{3} \mathrm{OH}-$ $\mathrm{H}_{2} \mathrm{O}(12: 1: 0.1$ to $0: 1: 0.1)$ as eluents and then was further purified by preparative TLC with $\mathrm{CHCl}_{3}-\mathrm{CH}_{3} \mathrm{OH}-\mathrm{H}_{2} \mathrm{O}(4: 1: 0.1)$ to afford 27 (6.0 mg), $18(2.1 \mathrm{mg})$, and $\mathbf{1}(2.8 \mathrm{mg})$

Houttuynoside A (1): Colorless syrup; $[\alpha]_{\mathrm{D}}^{25}-21.0^{\circ}(c=0.06, \mathrm{MeOH})$ $\mathrm{UV}(\mathrm{MeOH}) \lambda_{\max }(\log \varepsilon) 320$ (2.54), 257 (2.54), 211 (3.51) nm; IR (KBr) $v_{\max } 3392(\mathrm{OH}), 1688(\mathrm{CO}) \mathrm{cm}^{-1} ;{ }^{1} \mathrm{H}-\mathrm{NMR}$ (acetone- $\left.d_{6}, 300 \mathrm{MHz}\right) \delta: 10.37$ $(1 \mathrm{H}, \mathrm{brs}, \mathrm{OH}), 7.88\left(2 \mathrm{H}, \mathrm{d}, J=8.6 \mathrm{~Hz}, \mathrm{H}-2^{\prime \prime},-6^{\prime \prime}\right), 7.50(1 \mathrm{H}, \mathrm{d}, J=2.9 \mathrm{~Hz}, \mathrm{H}-$ 2), $7.33(1 \mathrm{H}, \mathrm{dd}, J=9.0,2.9 \mathrm{~Hz}, \mathrm{H}-6), 6.90\left(2 \mathrm{H}, \mathrm{d}, J=8.6 \mathrm{~Hz}, \mathrm{H}-3^{\prime},-5^{\prime \prime}\right)$, $6.79(1 \mathrm{H}, \mathrm{d}, J=9.0 \mathrm{~Hz}, \mathrm{H}-5), 4.90\left(1 \mathrm{H}, \mathrm{d}, J=7.2 \mathrm{~Hz}, \mathrm{H}-1^{\prime}\right), 4.70(1 \mathrm{H}$, dd, $\left.J=11.7,1.5 \mathrm{~Hz}, \mathrm{H}-6^{\prime}\right), 4.33\left(1 \mathrm{H}, \mathrm{dd}, J=11.7,7.2 \mathrm{~Hz}, \mathrm{H}-6^{\prime}\right), 3.84(3 \mathrm{H}, \mathrm{s}$, $\left.\mathrm{OCH}_{3}-7\right), 3.82\left(1 \mathrm{H}, \mathrm{m}, \mathrm{H}-5^{\prime}\right), 3.58-3.46\left(3 \mathrm{H}, \mathrm{m}, \mathrm{H}-2^{\prime},-3^{\prime},-4^{\prime}\right) ;{ }^{13} \mathrm{C}-\mathrm{NMR}$ (acetone- $\left.d_{6}, 100 \mathrm{MHz}\right) \delta: 170.2(\mathrm{C}-7), 165.8\left(\mathrm{C}-7^{\prime \prime}\right), 162.1\left(\mathrm{C}-4^{\prime \prime}\right), 157.1(\mathrm{C}-$ 2), 150.3 (C-1), $131.8\left(\mathrm{C}-2^{\prime \prime},-6^{\prime \prime}\right), 126.3$ (C-4), 121.7 (C-1"), 118.1 (C-3), 117.6 (C-6), 115.3 (C-3", -5"'), 112.3 (C-5), 102.4 (C-1'), 77.1 (C-3'), 74.5 $\left(\mathrm{C}-5^{\prime}\right), 73.9\left(\mathrm{C}-2^{\prime}\right), 70.9\left(\mathrm{C}-4^{\prime}\right), 64.0\left(\mathrm{C}^{\prime} 6^{\prime}\right), 52.2\left(\mathrm{OCH}_{3}-7\right)$; FAB-MS $m / z$ : $451[\mathrm{M}+\mathrm{H}]^{+}$; HR-FAB-MS m/z: $451.1244[\mathrm{M}+\mathrm{H}]^{+}\left(\right.$Calcd for $\mathrm{C}_{21} \mathrm{H}_{23} \mathrm{O}_{11}$, 451.1240).

Houttuynamide A (2): Colorless syrup; UV (MeOH) $\lambda_{\max }(\log \varepsilon) 286$ (3.90), 278 (3.90), 258 (4.10), 205 (4.60) nm; IR (KBr) $v_{\max } 3353(\mathrm{OH})$, 2924, 1700 (CO), $1612 \mathrm{~cm}^{-1}$; ${ }^{1} \mathrm{H}-\mathrm{NMR}\left(\mathrm{CD}_{3} \mathrm{OD}, 500 \mathrm{MHz}\right) \delta: 7.24(1 \mathrm{H}, \mathrm{d}$, $J=2.0 \mathrm{~Hz}, \mathrm{H}-2), 7.15(1 \mathrm{H}, \mathrm{dd}, J=8.4,2.0 \mathrm{~Hz}, \mathrm{H}-6), 7.06(2 \mathrm{H}, \mathrm{d}, J=8.6 \mathrm{~Hz}$,
H-2', $\left.-6^{\prime}\right), 6.78(1 \mathrm{H}, \mathrm{d}, J=8.4 \mathrm{~Hz}, \mathrm{H}-5), 6.71\left(2 \mathrm{H}, \mathrm{d}, J=8.6 \mathrm{~Hz}, \mathrm{H}-3^{\prime},-5^{\prime}\right)$, $5.00\left(1 \mathrm{H}\right.$, br s, OH), $3.49\left(2 \mathrm{H}, \mathrm{t}, J=7.5 \mathrm{~Hz}, \mathrm{CH}_{2}-8^{\prime}\right), 2.78(2 \mathrm{H}, \mathrm{t}, J=7.5 \mathrm{~Hz}$, $\left.\mathrm{CH}_{2}-7^{\prime}\right) ;{ }^{13} \mathrm{C}-\mathrm{NMR}\left(\mathrm{CD}_{3} \mathrm{OD}, 125 \mathrm{MHz}\right) \delta: 170.3(\mathrm{C}-7), 156.9\left(\mathrm{C}-4^{\prime}\right), 150.0$ (C-4), 146.3 (C-3), 131.5 (C-1'), 130.8 (C-2', -6' ), 127.2 (C-1), 120.5 (C-6), $116.3\left(\mathrm{C}-3^{\prime}\right.$, -5' $\left.^{\prime}\right), 115.8$ (C-5), 115.7 (C-2), 42.9 (C-8'), 35.9 (C-7'); EI-MS $m / z 273[\mathrm{M}]^{+}$(38); HR-EI-MS m/z: $273.1004[\mathrm{M}]^{+}$(Calcd for $\mathrm{C}_{15} \mathrm{H}_{15} \mathrm{NO}_{2}$, 273.1001).

Acid Hydrolysis of 1 A solution of all houttuynoside A (1) (1 mg) in $0.2 \mathrm{M} \mathrm{HCl}$ (dioxane- $\mathrm{H}_{2} \mathrm{O}, 1: 1,2.0 \mathrm{ml}$ ) was heated at $95^{\circ} \mathrm{C}$ for $1 \mathrm{~h}$ under an $\mathrm{Ar}$ atmosphere. The reaction mixture was chromatographed on a Sephadex LH-20 column eluted with $\mathrm{H}_{2} \mathrm{O}$ to afford the sugar fraction. The sugar fraction was analyzed by HPLC under the following conditions: column, Aminex HPX-87H $(7.8 \mathrm{~mm}$ i.d. $\times 300 \mathrm{~mm}, 5 \mathrm{~mm}$, Bio-Rad Laboratories, Hercules, CA, U.S.A.); solvent, $5 \mathrm{mM} \mathrm{H}_{2} \mathrm{SO}_{4}$; flow rate, $0.6 \mathrm{ml} / \mathrm{min}$; detection, RI and OR. Identification of D-glucose present in the sugar fraction was carried out by comparison of its retention time and polarity with those of an authentic sample: $t_{\mathrm{R}}(\mathrm{min}), 8.99$ (D-glucose, positive polarity)

Cell Culture and Viruses Vero cells were cultured in minimal essential medium (MEM; GIBCO, Grand Island, NY, U.S.A.) supplement with 10\% fetal calf serum (FCS; Hyclone, Logan, UT, U.S.A.), $100 \mathrm{U} / \mathrm{ml}$ penicillin, and $100 \mu \mathrm{g} / \mathrm{ml}$ streptomycin and incubated at $37^{\circ} \mathrm{C}$ in a $5 \% \mathrm{CO}_{2}$ incubator. To prepare HSV-1 (KOS strain, VR-1493, ATCC) stocks, Vero cells were infected by HSV-1 at a multiplicity of infection (m.o.i.) of 3 plaque forming units (PFU)/cell and harvested at $24 \mathrm{~h}$ postinfection and centrifuged at $1500 \times \boldsymbol{g}$ (Centrifuge $5810 \mathrm{R}$, Eppendorf) at $4{ }^{\circ} \mathrm{C}$ for $20 \mathrm{~min}$. The supernatant was collected and stored at $-70^{\circ} \mathrm{C}$ for use.

Plaque Reduction Assay The assay followed procedures described previously. ${ }^{35)}$ Vero cells $\left(3.5 \times 10^{5} /\right.$ dish) were overlaid with test compounds $(100 \mu \mathrm{M})$ and 100 plaque forming units (PFU) of HSV-1 were added to each dish. The viruses were adsorbed for $1 \mathrm{~h}$ at $37^{\circ} \mathrm{C}$ and $1 \%$ methylcellulose was added to each well. After $5 \mathrm{~d}$, the virus plaques formed in Vero cells were counted by crystal violet staining. The activities of test compounds and acyclovir for inhibition of plaque formation were calculated.

Antioxidant Assay The antioxidant assay was based on methods reported by Mellors and Tappel. ${ }^{36}$ ) The percentage values of inhibition were recorded after incubating for $30 \mathrm{~min}$.

Antityrosinase Assay The antityrosinase assay was based on the method of Bernard and Berthon. ${ }^{37}$

Acknowledgements The authors are grateful for financial support from the National Science Council, Taiwan, Republic of China (NSC 96-2628-M006-002) awarded to T. S. Wu.

\section{References}

1) Hayashi K., Kamiya M., Hayashi T., Planta Med., 61, 237-241 (1995).

2) Li G. Z., Chai O. H., Lee M. S., Han E. H., Kim H. T., Song C. H., Biol. Pharm. Bull., 28, $1864-1868$ (2005).

3) Chang J. S., Chiang L. C., Chen C. C., Liu L. T., Wang K. C., Lin C. C., Am. J. Chin. Med., 29, 303-312 (2001).

4) Kim S. K., Ryu S. Y., No J., Choi S. U., Kim Y. S., Arch. Pharm. Res., 24, 518-521 (2001).

5) Wang D., Yu Q. H., Eikstadt P., Hammond D., Feng Y., Chen N., Intern. Immunopharmacol., 2, 1411-1418 (2002).

6) Cho E. J., Yokozawa T., Rhyu D. Y., Kim S. C., Shibahara N., Park J. C., Phytomedicine, 10, 554-551 (2003)

7) Priestap H. A., Phytochemistry, 24, 849-852 (1985).

8) Lo W. L., Chang F. R., Wu Y. C., J. Chin. Chem. Soc., 47, 1251-1256 (2000).

9) Achari B., Bandyopadhyay S., Chakravarty A. K., Pakrashi S. C., Org. Magn. Reson., 22, 741-746 (1984).

10) Chen C. Y., Chang F. R., Wu Y. C., J. Chin. Chem. Soc., 44, 313-319 (1997).

11) Bate R. B., Janda K. D., Synthesis, 4, 310-311 (1984).

12) Ghosh P., Ghosh M. K., Thakur S., Dan J., Akihisa T., Tamura T. Kimura Y., Phytochemisry, 37, 757-760 (1994).

13) Lampert H., Mikenda W., Karpfen A., Kahlig H., J. Phys. Chem. A, 101, 9610-9617 (1997).

14) Pouchert C. J., Behnke J., "The Aldrich Library of ${ }^{13} \mathrm{C}$ and ${ }^{1} \mathrm{H}$ FTNMR Spectra," Vol. 2, Aldrich Chemical Company Inc., New York, 1993, p. 1394C.

15) Kergomard A., Renard M. F., Agric. Biol. Chem., 50, 2913-2914 (1986).

16) Miles H. T., Smyrniotis P. Z., Stadtman E. R., J. Am. Chem. Soc., 81, 
1946-1949 (1959).

17) Zalibera L., Milata V., Llavsky D., Magn. Reson. Chem., 36, 681-684 (1998).

18) Chiji H., Arakawa Y., Ueda S., Kuroda M., Izawa M., Phytochemistry, 25, 281-282 (1986).

19) Jong T. T., Jean M. Y., J. Chin. Chem. Soc., 40, 399-402 (1993).

20) Netting A. G., Millborrow B. V., Duffield A. M., Phytochemistry, 21, 385-389 (1982).

21) Chen K. S., Chang F. R., Chia Y. C., Wu T. S., Wu Y. C., J. Chin. Chem. Soc., 45, 103-110 (1998).

22) Broom S. J., Ede R. M., Wilkins A. L., Tetrahedron Lett., 33, $3197-$ 3200 (1992).

23) Kuima H., Otsuka H., Ide T., Ogimi C., Hirata E., Takushi A., Takeda Y., Phytochemistry, 42, 723-727 (1996).

24) Wu T. S., Chan Y. Y., J. Chin. Chem. Soc., 41, 209-212 (1994).

25) Lee C. K., Lu C. K., Kuo Y. H., Chen J. Z., Sun G. Z., J. Chin. Chem. Soc., 51, 437-442 (2004).

26) Wilson S. C., Howard P. W., Forrow S. M., Hartley J. A., Adams L. T., Jenkins T. C., Kelland L. R., Thurston D. E., J. Med. Chem., 42,
4028-4041 (1999).

27) Zhang H. L., Nagatsu A., Okuyama H., Mizukami H., Sakakibara J., Phytochemisry, 48, 665-668 (1998).

28) Wen L. L., Chang F. R., Hsieh T. J., Wu Y. C., J. Chin. Chem. Soc., 49, 421-426 (2004).

29) Carter M. J., Fleming I., Percival A., J. Chem. Soc. Perkin Trans. 1, 1981, 2415-2434 (1981).

30) Schmitt B., Schneider B., Phytochemistry, 52, 45-53 (1999)

31) Babu K. S., Raju B. C., Srinivas P. V., Rao A. S., Kumar S. P., Rao J. M., Chem. Lett., 32, 704-705 (2003).

32) Withopf B., Richling E., Roscher R., Schwab W., Schreier P., J. Agric Food Chem., 45, 907-911 (1997).

33) Nozakim H., Suzuki H., Hirayana T., Kasai R., Wu R. Y., Lee K. H., Phytochemistry, 25, 479 (1986).

34) Kuo Y. H., Li Y. C., J. Chin. Chem. Soc., 44, 321-325 (1997)

35) Kuo Y. C., Lin L. C., Tsai W. J., Chou C. J., Kung S. H., Ho Y. H., Antimicrob. Agents Chemother, 46, 2854-2864 (2002).

36) Mellors A., Tappel A. L., J. Biol. Chem., 241, 4353-4356 (1966).

37) Bernard P., Berthon J. Y., Int. J. Cosmet. Sci., 22, 219-226 (2000). 